\title{
The impact of applying different metrics in target definitions: lessons for policy design
}

\author{
Robert Harmsen
}

Received: 17 December 2014 / Accepted: 28 April 2016/Published online: 23 May 2016

(C) The Author(s) 2016. This article is published with open access at Springerlink.com

\begin{abstract}
The objective of this paper is to analyse the impact of the use of different metrics in the EU renewable energy target definition. The analysis, using a case study of the Dutch renewable energy support for illustration, reveals that a target based on primary energy would have led to a ranking in which renewable electricity options would predominantly have been considered cheaper for realizing the target. As a primary energy-based target is more closely linked to overarching objectives of the EU Renewable Energy Directive, such as climate change and energy security, this implies that the least cost realization of the current final energybased target does not necessarily lead to the least cost mix for reducing $\mathrm{CO}_{2}$ emissions or avoiding fossil primary energy. The Dutch case study also shows that the budget allocation in favour of renewable heat and gas options was not only a direct consequence of the final energy-based target but also because of the limited annual budget available for support in the analysed period. With the increase of the support budget since 2013, the budget allocation between the renewable energy categories has become more balanced. Lessons for policy design are provided by highlighting the importance of side-effects which are often insufficiently recognized in the design stage of targets. In the case of the
\end{abstract}

An earlier version of this article has been presented at the 2014 IEPPEC conference in Berlin (Harmsen 2014).

R. Harmsen $(\bowtie)$

Copernicus Institute of Sustainable Development, Utrecht University, Heidelberglaan 2, 3584 CS Utrecht, The Netherlands e-mail: r.harmsen@uu.nl
EU renewable energy target, the choice for a final energy-based target did, on the one hand, not consider the consequences for least cost target achievement (negative side-effect), but on the other provided an incentive to pay more attention to renewable heat (positive sideeffect).

Keywords Renewable energy · Target definition · Cost-effectiveness

\section{Introduction}

The Climate and Energy Package is the backbone of Europe's 2020 targets, which are often referred to as the 20/20/20 targets (European Commission 2008a), including a binding $20 \%$ reduction of GHG emissions compared to 1990 , indicative $20 \%$ energy savings and a binding share of $20 \%$ renewable energy in total final energy consumption in 2020. The latter target is the main objective of Directive 2009/28/EC on the promotion of the use of energy from renewable sources (hereafter: 2009 RES Directive).

In the 2007, Renewable Energy Roadmap (European Commission 2007), a $20 \%$ renewable energy target in gross inland consumption (i.e. primary energy) by 2020 was considered feasible and desirable. However, in the 2009 RES Directive, a $20 \%$ renewable energy target in gross final energy consumption was set. The reason for the European Commission to change the metric from primary to final energy will be discussed later in this paper. Our research interest concerns the impact such 
change in metrics may have. Expressing the implementation potential of a renewable energy technology in petajoule (PJ), primary or final energy will generally result in different outcomes. If the total investment costs for realizing the implementation potential do not change (i.e. are not affected by changing the metrics), the costeffectiveness, defined by Vedung (2013) as the effect of a policy program or instrument in physical terms (e.g. PJ) divided by its costs, will change. In that case, the text of the 2009 RES Directive, stating in recital 9 that renewable energy is "... to be introduced in a costeffective way" (European Parliament and Council 2009, L140/17), leaves room for questions: a costeffective introduction of the EU renewable energy target would mean the implementation of that mix of least cost renewable energy technologies which are needed to meet the target, but how this least cost mix looks like would be unclear as depending on the physical term used in the equation (PJ primary or final energy). This leads to the objective of this paper: to analyse the impact of the use of different metrics/physical terms in the EU renewable energy target definition and to identify lessons for policy design.

In the following section, some relevant definitions used in the analysis are provided. Then, the paper continues by exploring the background of Europe's 2020 renewable energy target in three steps, focusing on (1) the reason for the EU for having a renewable energy target, (2) the considerations behind Europe's choice for having a target based on final energy and (3) a positive side-effect of having a final energy-based target. In the next step, the paper elaborates on a case study for the Netherlands, providing some background information on renewable energy in the Netherlands, explaining the Dutch support scheme for renewable energy, analysing the technology preference in the scheme, and analysing the actual budget allocation in the support scheme. The paper ends with a discussion and conclusion.

\section{Definitions}

Energy

For the right interpretation of energy policy targets, it is important to understand how energy is dealt with in statistics. Good guidance is offered by the Energy Statistics Manual of the IEA and Eurostat (2005).
In physics, a basic distinction is made between primary energy (coal, oil, natural gas, uranium, wind, solar, hydro, etc.) and secondary energy (electricity, heat, transport fuels, mechanical energy). Secondary energy is not reported in statistics. Statistics do report primary energy which is referred to as gross inland consumption and defined as primary production (coal mining e.g.) plus imports, recovered products and stock change, less exports and fuel supply to maritime bunkers. Gross inland consumption can also be defined as the sum of gross final energy consumption plus the conversion losses for producing heat and electricity in the energy branch.

Final energy consumption can also be found in statistics, both as gross and net. Gross final energy consumption is the net final energy consumption plus the self-consumption by the energy branch for producing electricity and heat production plus the distribution and transmission losses. Net final energy consumption is the energy commodities delivered for energy purposes to the energy demand sectors (industry, transport, households, services, etc.).

Final energy consumption is often confused with secondary energy. This confusion can be clarified with two examples:

- Heat produced by an individual household or industrial boiler is secondary energy (the product of converting primary energy) but not final energy: In statistics it is not heat from the boiler which is reported but the delivery of the boiler fuel (e.g. natural gas) to the end user.

- District heat is also secondary energy (again, the product of converting primary energy). However, district heat from a central boiler or a CHP plant is also considered final energy as it is the district heat which is delivered/sold to the end-user (and not the fuel for producing the district heat).

The definitions provided above imply that in some cases there is no or hardly any difference between primary energy and final energy. An example is natural gas delivered to end-users which is both primary and final energy. Another example is crude oil and transport fuels, where the difference between primary and final energy is small when the conversion process is very efficient (>95\%).

Big differences come into play when considering electricity production which, depending on the fuel, type 
of technology and age of the power plant, includes massive conversion losses. The conversion efficiency for modern large-scale fossil fuel-based electricity production typically range between 40 and $50 \%$ (for natural gas even a bit higher) which means that the difference between primary and final energy is a factor 2-2.5, and that $50-60 \%$ of the energy content of the primary energy is lost.

For solar, wind and hydro power, one single default efficiency applies. Eurostat and IEA use the "Physical Energy Content Method" for reporting renewable energy statistics (IEA and Eurostat 2005). In this method, primary energy is defined as the first commodity which can be converted to secondary energy (heat, electricity, etc.). For hydro, wind and solar power, the first usable commodity is the electricity produced, which means that 1 unit of primary energy converts to 1 unit of electricity. This implies a conversion efficiency of $100 \%$ (Harmsen et al. 2011).

The reader should note that also another approach for dealing with wind, solar and hydro power is widely applied. This is the so-called substitution method. In this method 1 unit of wind electricity is considered to substitute 1 unit of fossil-based electricity, which means that 1 unit of wind electricity avoids the use of 2-2.5 units of fossil primary energy (depending on the conversion efficiency assumed in the calculation). Although the substitution method is not any longer the dominant method used in statistics, the method is still valuable in discussions on e.g. energy security in which renewable energy production is looked at in terms of avoided fossil primary energy. ${ }^{1}$

\section{Cost-effectiveness}

In renewable energy literature, cost-effectiveness is used for comparing policy instruments (e.g. Kle $\beta$ mann et al. 2011; Haas et al. 2011; Toke 2007; Palmer and Burtraw 2005) or for comparing

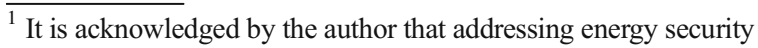
in terms of avoided fossil primary energy only is rather simplistic. However, as a proxy for energy security, it offers a better indicator than final energy. It is also acknowledged that the supply insecurity of fossil fuels differs. Coal e.g. is generally considered a more secure fuel than natural gas and oil. Interestingly, the dominant import country to the EU28 of both crude oil, natural gas and coal is Russia (Eurostat 2013). For the Netherlands, Russia is the number one import country for oil, number two for natural gas and number three for coal.
}

the specific costs of renewable energy technologies (Blarke and Lund 2008; Del Rio and Cerda 2014). Sometimes, cost-effectiveness is also referred to as cost-efficiency (see e.g. Kleßmann 2011). Vedung's (2013) definition of cost-effectiveness is the effect of a policy instrument in physical terms divided by its costs (in a monetary unit). Cost-effectiveness is distinguished from cost-benefit which is the value (in a monetary unit) of the effect of a program (or policy instrument) divided by its costs (in a monetary unit). "Efficiency" is used a synonym by Vedung for both cost-effectiveness and cost-benefit.

In this paper, Vedung's definition of costeffectiveness is adopted and used for comparing renewable energy technologies in a specific support scheme, where the most cost-effective technology is the one needing the least support. When taking the inverse of Vedung's equation, the numerator deals with the support costs (the surplus production costs of a technology compared to the fossil energy based alternative). ${ }^{2}$ For the denominator, different choices can be made regarding the physical term used for expressing the effect of a policy instrument. In case of the EU renewable target, the denominator could be the unit of renewable energy produced (cost-effectiveness $=$ support costs per kilowatt hour renewable energy produced). Alternatively, when e.g. two more overarching objectives of the 2009 RES Directive are taken upfront, i.e. improving energy security or mitigating climate change, the denominator becomes the unit of fossil energy or $\mathrm{CO}_{2}$ emission avoided (cost-effectiveness $=$ support costs per kilowatt hour of fossil energy avoided or ton of $\mathrm{CO}_{2}$ avoided).

Knowing which renewable energy technology shows the biggest payoff per euro of support (the most costeffective technology) allows for a preference ranking which can be used by governments in the allocation of budget. The reader should note that "biggest pay-off per euro of support" can be looked at differently:

- From a short-term perspective. This is the perspective used in this paper since it connects to the objective of the Dutch renewable energy support scheme,

\footnotetext{
${ }^{2}$ If cost-effectiveness would be looked at from a societal point of view rather than a support cost point of view, the numerator would be the net sum of all costs and benefits for society. In that case support costs would be left out of the equation since support is a zero-sum game from a societal perspective.
} 
our case study (see "Case study Netherlands" section).

- From a longer term perspective, anticipating on the need for timely development of innovative and more expensive technologies in order to avoid future supply chain constraints that could hamper achievement of e.g. long term climate goals. In this case costeffectiveness is referred to as dynamic efficiency (Kleßmann et al. 2013).

\section{The background of the EU 2020 renewable energy target}

Why does Europe have a renewable energy target?

Recital 1 of the 2009 RES Directive (European Parliament and Council 2009, L140/16) states that "The control of European energy consumption and the increased use of energy from renewable sources, together with energy savings and increased efficiency, constitute important parts of the package of measures needed to reduce greenhouse gas emissions [.....]. Those factors also have an important part to play in promoting the security of energy supply, promoting technological development and innovation and providing opportunities for employment and regional development, especially in rural and isolated areas." This means that climate change mitigation and improvement of security of supply are (among others) considered overarching objectives of the Directive.

It should be noted that at the time of designing the EU Climate and Energy Package it was projected that the $20 \%$ GHG reduction target could be achieved without a binding renewable energy target (European Commission 2008b). Still, a legally binding renewable energy target was introduced. The European Commission felt the urgency of strengthening and expansion of the EU regulatory framework as the (indicative) $12 \%$ renewable energy target for 2010 (set in 1997) would not be met (European Commission 2007). The growth of the renewable energy sector (not so much needed for achieving the 2020 GHG target but crucial for mitigating climate change beyond 2020) was hampered by administrative problems, opaque and discriminating rules for grid access and lack of information.

Before 2009, the EU had a Renewable Electricity Directive (with a target for 2010) and a Biofuels Directive, but lacked a directive covering renewable heat. As a consequence, in most Member States, the growth of renewable heat was limited (European Commission 2007) and most support was given to renewable electricity.

Why does Europe have a renewable energy target based on final energy?

As mentioned in the introduction of this paper in the 2007 Renewable Energy Roadmap (European Commission 2007), a $20 \%$ renewable energy target in gross inland consumption (i.e. primary energy) was formulated, whereas in the 2009 RES Directive, a $20 \%$ renewable energy target in gross final energy consumption was set. The argument for making this change from primary to final can be found in the impact assessment of the Climate and Energy Package (European Commission 2008b). This document points at the expected penalization of so-called non-thermal renewable energy sources such as wind and solar power in case a renewable energy target based on primary energy should be chosen. As explained in the renewable energy roadmap (European Commission 2007, p.6): "As biomass is a thermal process and wind is not, one unit of final energy produced from biomass counts 2.4 times more than one unit of final energy produced from wind and counted in primary energy." In other words: the contribution of 1 unit of biomass electricity towards a renewable energy target based on primary energy is 2.4 times more than the contribution of 1 unit of wind electricity. ${ }^{3}$ Table 1 shows (grey-coloured row) that based on 2010 statistics and the latest 2020 projection for the EU (Capros et al. 2013), it is indeed true that the contribution to the renewable energy target of wind, solar an hydro power is bigger in case of a target based on final energy than in case of a target based on primary energy: in 2010 (statistics) $33 \%$ of total renewable energy comes from wind, solar and hydro power when considering final energy, whereas this percentage is "only" $26 \%$

\footnotetext{
$\overline{3}$ Note that 2.4 implies a conversion efficiency (fuel-to-electricity) of $41.7 \%$.
} 
Table 1 Share of renewable energy sources in the $2013 \mathrm{EU}$ reference scenario (data from Capros et al. (2013) aggregated by the author)

\begin{tabular}{|c|c|c|c|c|}
\hline & \multicolumn{2}{|c|}{$\begin{array}{l}\text { Primary energy } \\
\text { [Mtoe] }\end{array}$} & \multicolumn{2}{|c|}{$\begin{array}{l}\text { Final energy } \\
\text { [Mtoe] }\end{array}$} \\
\hline & 2010 & 2020 & 2010 & 2020 \\
\hline Nuclear electricity & 237 & 193 & 79 & 64 \\
\hline Fossil electricity & 383 & 304 & 147 & 124 \\
\hline Biomass electricity & 34 & 49 & 13 & 20 \\
\hline Other RES electricity, mainly wind, hydro, solar & 47 & 86 & 47 & 86 \\
\hline Fossil heat, cooling, transport & 963 & 889 & 790 & 723 \\
\hline RES heat, cooling, transport & 103 & 143 & 82 & 119 \\
\hline RES share total & $10 \%$ & $17 \%$ & $12 \%$ & $20 \%$ \\
\hline \multicolumn{5}{|l|}{ Of which: } \\
\hline Other RES electricity, mainly wind, hydro and solar & $26 \%$ & $31 \%$ & $33 \%$ & $38 \%$ \\
\hline Biomass electricity & $18 \%$ & $18 \%$ & $9 \%$ & $9 \%$ \\
\hline RES heat, cooling, transport & $56 \%$ & $51 \%$ & $58 \%$ & $53 \%$ \\
\hline
\end{tabular}

when considering primary energy; in 2020 (projection) $38 \%$ of total renewable energy comes from wind, solar and hydro power when considering final energy, whereas this percentage is "only" $31 \%$ when considering primary energy.

A positive side-effect of choosing a final energy-based target

Although the argument of an "undervalued" contribution to the renewable energy target by wind, solar and hydro power (but especially fastgrowing wind energy) is true, it only shows one side of the coin. The choice for a final energybased target could also have been assessed by comparing its consequences for renewable electricity at the one side and renewable heat at the other. A final renewable energy target implies that 1 unit of renewable electricity provides the same amount of renewable energy as 1 unit of renewable heat, whereas a primary renewable energy target would mean that the contribution of 1 unit of biomass electricity would be $2-2.5$ times more than the contribution of 1 unit of renewable heat. This implies that the choice of a final renewable energy target offers an incentive to renewable heat compared to biomass electricity. Biomass is given in italics since the implication is not a general relation between renewable electricity and other renewable energy sources. Since the primary conversion factor of wind, solar and hydro power used in statistics is $100 \%$ (see "Energy"section), the difference between wind, solar and hydro power on the one hand, and renewable heat on the other regarding the contribution to a final or primary renewable energy target is much smaller (since renewable heat conversion efficiencies are also high).

So, the choice for a target based on primary energy would mean that the contribution of 1 unit of wind and solar power to the renewable energy target is smaller than the contribution of 1 unit of biomass electricity. The choice for a target based on final energy would guarantee a level playing field for renewable electricity (each unit of electricity, whether biomass or wind, provides the same contribution to the target) but would also make renewable heat more attractive compared to biomass electricity (a unit of heat provides the same contribution to the target as a unit of electricity). The latter-though not explicitly mentioned as an argument for setting a renewable energy target based on final energy by the European Commission-supports one of the objectives of the 2009 RES Directive, i.e. to make growth of renewable heat more attractive to Member States. As the European Commission (2015, p3) puts it: "Renewable heating is increasingly being used as a cost-efficient and secure alternative to fossil fuels in Member States in district heating and at local level." 


\section{Case study Netherlands}

Context

Like the other EU Member States, the Netherlands have to contribute to the 2020 EU renewable energy target. The legally binding target for the Netherlands is to increase its share of renewable energy in final energy consumption from $2.4 \%$ in 2005 to $14 \%$ in 2020 (European Parliament and Council 2009).

The Dutch progress in deploying renewable energy is slow. Together with France, the Netherlands failed to meet its 2011/2012 interim target. The European Commission doubts whether the Dutch policies are sufficient and effective for meeting the 2020 target (European Commission 2015).

With the implementation of an overall EU renewable energy target, rather than separate targets for renewable electricity and biofuels and no target for renewable heat, the Dutch support system for renewables changed and broadened its scope to renewable heat which was recognized as a cost-effective option for meeting the 2020 target (Statistics Netherlands (CBS) 2015).

The Dutch support scheme for renewable energy: $\mathrm{SDE}+{ }^{4}$

The main instrument in the Dutch policy package for achieving the 2020 target is the SDE+. The main characteristics of the instrument are (Statistics Netherlands (CBS) 2014):

- Compared to the previous support schemes, it stimulates not only renewable electricity but also renewable heat and green gas.

- The subsidy is a feed-in premium and, as such, dependent on the market price of electricity and natural gas (the predominant fuel for heating in the Netherlands). The higher the market price of electricity/gas, the smaller the difference between conventional and renewable energy and therefore the lower the subsidy.

- For each, year a maximum subsidy budget for new projects is set.

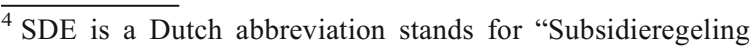
Duurzame Energie".
}

- There are no fixed rates per technology, and there is no separate budget per technology.

- The overall budget is allocated in six stages. For each stage a maximum amount of euros per unit of final energy is set for each technology.

- Stage 1 starts with relatively low rates for which project developers can apply.

- At the end of stage 1, it is checked whether there is budget left. If this is the case, then stage 2 starts with a higher rate. And so on, until the total budget has been allocated.

The idea behind the stages is to prioritize the cheapest renewable energy options and to only allow more expensive options if budget remains. As such, the Dutch government aims for a costeffective achievement of the target, focussing its support on the options having the lowest production costs per unit of final energy today. Dynamic efficiency is not considered in the SDE+ (but addressed in renewable policy instruments that stimulate Research and Development).

Changing the metrics: leading to a different cost ranking

When considering renewable energy as a means to combat climate change or to increase the security of energy supply, it can be argued that the most costeffective options are the ones substituting the most fossil primary energy or reducing the most $\mathrm{CO}_{2}$ emissions, and not the ones being the cheapest in terms of euros per unit of final renewable energy. The choice of the denominator has an impact on the cost ranking of the technologies, which is shown in Table 2 for three different objectives: (1) costeffective achievement of the final renewable energy target (the SDE+ approach), (2) cost-effective contribution of renewable energy to substituting fossil primary energy and (3) cost-effective contribution of renewable energy to mitigating $\mathrm{CO}_{2}$ emissions.

Table 2 is developed using the SDE + calculation model developed by ECN (the principle advisor of the Dutch government regarding the base SDE+ rates). ${ }^{5}$ For the calculations, ECN's input parameters were used (see Lensink 2013). In addition, for electricity production, a reference efficiency value of

\footnotetext{
$\overline{5}$ The SDE calculation model is accessible via https://www.ecn.nl/ projects/sde/sde-2014/.
} 
Table 2 Ranking of technologies using different objectives (2014 calculation parameters)

\begin{tabular}{|c|c|c|c|}
\hline & $\begin{array}{l}\text { SDE+ priority ranking } \\
\text { (support costs in euro/GJ final energy }{ }^{12} \text { ) }\end{array}$ & $\begin{array}{l}\text { Priority ranking by substituted fossil } \\
\text { primary energy } \\
\text { (support costs in euro per GJ fossil primary } \\
\text { energy avoided) }\end{array}$ & $\begin{array}{l}\text { Priority ranking by avoided } \mathrm{CO}_{2} \text { emissions } \\
\text { (support costs in euro per ton } \mathrm{CO}_{2} \text { avoided) }\end{array}$ \\
\hline \multirow[t]{31}{*}{$\begin{array}{l}\text { Most cost } \\
\text { effective }\end{array}$} & $\begin{array}{l}€ 6.0 / G J \text { - boiler fired by solid biomass } \geq 5 \\
\text { MWth }(\mathrm{H})\end{array}$ & Hydropower renovation & Hydropower renovation \\
\hline & $\begin{array}{l}€ 6.1 / G J \text { - Deep geothermal - low } \\
\text { temperature }(H)\end{array}$ & Onshore wind (stage 1) & Onshore wind (stage 1) \\
\hline & Boiler fired by solid biomass $<5 \mathrm{MWth}(\mathrm{H})$ & Boiler fired by solid biomass $<5 \mathrm{MWth}$ & Boiler fired by solid biomass $<5 \mathrm{MWth}$ \\
\hline & Deep geothermal - high temperature $(\mathrm{H})$ & All feedstock digestion heat & $€ 72.3 /$ ton $\mathrm{CO}_{2}$ - Onshore wind (stage 2) \\
\hline & All feedstock digestion heat $(\mathrm{H})$ & $€ 5.0 / \mathrm{GJ}$ - Onshore wind (stage 2) & Onshore wind $>=6 \mathrm{MW}$ (stage 2) \\
\hline & Hydropower renovation $(\mathrm{E})$ & Onshore wind $>=6 \mathrm{MW}$ (stage 2 ) & WWTP thermal pressure hydrolysis \\
\hline & All feedstock digestion gas (G) & WWTP thermal pressure hydrolysis & All feedstock digestion heat \\
\hline & Boiler fired by liquid biomass $(\mathrm{H})$ & $\begin{array}{l}€ 5.4 / G J \text { - boiler fired by solid biomass } \geq 5 \\
\text { MWth }\end{array}$ & $\begin{array}{l}€ 93.8 / \text { ton } \mathrm{CO}_{2} \text { - onshore wind }>=6 \mathrm{MW} \\
\text { (stage 3) }\end{array}$ \\
\hline & Manure co-digestion heat $(\mathrm{H})$ & $\begin{array}{l}€ 5.5 / G J \text { - deep geothermal - low } \\
\text { temperature }\end{array}$ & Onshore wind (stage 3) \\
\hline & Thermal conversion biomass (>10 MWe) (E) & $€ 6.5 / G J$ onshore wind $>=6 \mathrm{MW}$ (stage 3 ) & $\begin{array}{l}€ 94.8 / \text { ton } \mathrm{CO}_{2} \text { boiler fired by solid biomass } \\
\geq 5 \mathrm{MWth}\end{array}$ \\
\hline & Manure co-digestion gas (G) & Onshore wind (stage 3) & $\begin{array}{l}€ 96.9 / \text { ton } \mathrm{CO}_{2} \text { - deep geothermal low } \\
\text { temperature }\end{array}$ \\
\hline & $\begin{array}{l}\text { All feedstock digestion (extended life) CHP } \\
(\mathrm{E} / \mathrm{H})\end{array}$ & $€ 7.5 / \mathrm{GJ}$ - onshore wind $>=6 \mathrm{MW}$ (stage 4$)$ & $\begin{array}{l}€ 108.9 / \text { ton } \mathrm{CO}_{2} \text { - onshore wind }>=6 \mathrm{MW} \\
\text { (stage 4) }\end{array}$ \\
\hline & Onshore wind (stage 1) (E) & Deep geothermal high temperature & Deep geothermal high temperature \\
\hline & \begin{tabular}{|l} 
Deep geothermal energy $\mathrm{CHP}(\mathrm{E} / \mathrm{H})$ \\
\end{tabular} & Boiler fired by liquid biomass & Boiler fired by liquid biomass \\
\hline & All feedstock digestion $\mathrm{CHP}(\mathrm{E} / \mathrm{H})$ & Manure co-digestion heat & $€ 160.1 /$ ton $\mathrm{CO}_{2}$ solar $\mathrm{PV}>15 \mathrm{~kW}_{\mathrm{p}}$ \\
\hline & WWTP thermal pressure hydrolysis (E) & All feedstock digestion gas & Wind in lake \\
\hline & $€ 11.7 / G J$ - Onshore wind (stage 2) (E) & $€ 11.1 / \mathrm{GJ}$ - Solar PV >15 kW & Manure co-digestion heat \\
\hline & Onshore wind $>=6 \mathrm{MW}$ (stage 2) $(\mathrm{E})$ & Wind in lake & All feedstock digestion gas \\
\hline & Agricultural digester $\mathrm{CHP}(\mathrm{E} / \mathrm{H})$ & All feedstock digestion (extended life) CHP & Hydro power new \\
\hline & $\begin{array}{l}€ 15.1 / \mathrm{GJ} \text { - onshore wind >= } 6 \mathrm{MW} \text { (stage 3) } \\
(\mathrm{E})\end{array}$ & Hydro power new & All feedstock digestion (extended life) CHP \\
\hline & Onshore wind (stage 3) (E) & All feedstock digestion CHP & $€ 235.0 /$ ton $\mathrm{CO}_{2}$ offshore wind \\
\hline & Manure co-digestion $\mathrm{CHP}(\mathrm{E} / \mathrm{H})$ & Thermal conversion biomass (>10 MWe) & All feedstock digestion CHP \\
\hline & Manure mono-digestion gas $(\mathrm{G})$ & Agricultural digester $\mathrm{CHP}$ & Thermal conversion biomass (>10 MWe) \\
\hline & $\begin{array}{l}17.6 / \mathrm{GJ} \text { - onshore wind >= } 6 \mathrm{MW} \text { (stage 4) } \\
(\mathrm{E})\end{array}$ & Manure co-digestion gas & Agricultural digester CHP \\
\hline & Solar thermal $>100 \mathrm{~m}^{2}(\mathrm{H})$ & $€ 16.2 / G J$ - Offshore wind & Manure co-digestion gas \\
\hline & Gasification gas (G) & Deep geothermal energy CHP & Deep geothermal energy $\mathrm{CHP}$ \\
\hline & $€ 25.8 / G J-$ Solar PV $>15 k^{2}$ (E) & Manure co-digestion CHP & Manure co-digestion CHP \\
\hline & Thermal conversion biomass (<10 MWe) (E) & Solar thermal $>100 \mathrm{~m}^{2}$ & Solar thermal $>100 \mathrm{~m}^{2}$ \\
\hline & Wind in lake (E) & Manure mono-digestion gas & Free tidal current energy \\
\hline & Hydro power new (E) & Free tidal current energy & Manure mono-digestion electricity \\
\hline & $€ 37.9 / G J$ - Offshore wind (E) & Thermal conversion $(<10 \mathrm{MWe})$ & Manure mono-digestion gas \\
\hline \multirow{2}{*}{$\begin{array}{l}\qquad \vee \\
\text { Least cost- } \\
\text { effective }\end{array}$} & Free tidal current energy $(E)$ & Manure mono-digestion electricity & Thermal conversion $(<10 \mathrm{MWe})$ \\
\hline & Manure mono-digestion electricity $(\mathrm{E})$ & Gasification gas & Gasification gas \\
\hline
\end{tabular}

$\mathrm{E}=$ electricity; $\mathrm{H}=$ heat; $\mathrm{E} / \mathrm{H}=$ combined generation of heat and power; $\mathrm{G}$ = gas

${ }^{11}$ Note that the ranking of technologies in this column is based on production costs (which is the approach followed in the SDE + ). A ranking based on support costs would be slightly different

${ }^{12}$ Note that these support costs are indicative. Actual support costs may be (slightly) higher or lower based on the amount of support asked for in the bidding stages

CHP combined heat and power 
$42.8 \%$ was used to calculate the substituted fossil primary energy and for heat production a reference efficiency value of $90 \%$ (Buck te et al. 2010). To calculate the avoided $\mathrm{CO}_{2}$ emissions, a $\mathrm{CO}_{2}$ intensity of $581 \mathrm{~kg} / \mathrm{MWh}$ electricity was used, ${ }^{6}$ and for natural gas (the predominant fuel for heating) a $\mathrm{CO}_{2}$ emission factor of $56.7 \mathrm{~kg} / \mathrm{GJ}$ (Buck et al. 2010). For two technologies, the calculations of the support costs when using different metrics is shown:

- Boiler fired by solid biomass $\geq 5 \mathrm{MWth}$ - renewable heat option

- SDE+ priority ranking: $€$ 6.0/GJ final energy (derived from the ECN calculation tool ${ }^{7}$ )

- Substituted fossil primary energy: $€ 6.0 /$ GJ fi$\mathrm{nal} \times 0.90 \mathrm{GJ}$ final/GJ primary $=€ 5.4 /$ GJ primary energy

- Avoided $\mathrm{CO}_{2}$ emissions: $€ 5.4 / \mathrm{GJ}$ primary energy $/ 56.7 \mathrm{~kg} \mathrm{CO} / \mathrm{GJ}$ primary energy $\times 1000$ ton $/ \mathrm{kg}=€ 94.8 /$ ton $\mathrm{CO}_{2}$

- Onshore wind (stage 2)-renewable electricity option

- $\quad$ SDE+ priority ranking: $€ 11.7 / G J$ final energy (derived from the ECN calculation tool)

- Substituted fossil primary energy: $€ 11.7 / \mathrm{GJ}$ final $\times 0.428 \mathrm{GJ}$ final/GJ primary $=€ 5.0 / \mathrm{GJ}$ primary energy ${ }^{8}$

- Avoided $\mathrm{CO}_{2}$ emissions: $€ 11.7 / \mathrm{GJ}$ final energy $\times 3.6 \mathrm{GJ} / \mathrm{MWh} / 581 \mathrm{~kg} \mathrm{CO} / \mathrm{MWh} \times 1000$ ton $/ \mathrm{kg}=€ 93.8 /$ ton $\mathrm{CO}_{2}$

For illustration, a few table cells are coloured and show the specific support costs to emphasize the changes in the priority ranking for the selected technologies based on the objective chosen. The grey (biomass boiler) and black (geothermal) marked table cells show technologies that lose their high ranking, whereas the wind (yellow, red, green, brown) and solar (blue) electricity options

\footnotetext{
${ }^{6}$ This value is similar to the $585 \mathrm{~kg} / \mathrm{MWh}$ found by Harmsen and Graus (2013) being the $\mathrm{CO}_{2}$ intensity in the Netherlands in 2008 excluding renewable electricity but corrected for cogenerated heat, grid losses and self-consumption of the power plants.

${ }^{7}$ The correction rates needed for this calculation are published in the Dutch State Journal (Staatscourant).

${ }^{8}$ This is calculated using the substitution method instead of the primary energy method (see "Energy" section).
}

significantly improve their position compared to other technologies. Table 2 results illustrate that in the SDE+ priority ranking, renewable electricity is having a less favourable position than renewable heat when euro per unit of final energy is used for cost-effectiveness calculations. Given the procedure of allocating SDE+ budget (see before; starting with the lowest cost options until the budget has been spent), this could lead to a penalization of lower ranked renewable electricity options compared to higher ranked renewable heat options. ${ }^{9}$

Figures 1 and 2 present the findings of Table 2 graphically. Figure 1 shows that for heat and gas options the difference between euro/GJ final or primary energy is small ( $x$-axis value $\approx y$-axis value), whereas for the electricity options, the euros/GJ primary are almost a factor 2.5 lower (which is explained by the $42.8 \%$ reference efficiency value used in the calculations).

Figure 2 shows that the electricity options become even more beneficial compared to the heat and gas options when looking at the euros per avoided ton $\mathrm{CO}_{2}$. This is explained by the use of a $\mathrm{CO}_{2}$ intensity factor for electricity of $581 \mathrm{~kg} / \mathrm{MWh}$ reflecting a mix of coal and natural gas, whereas the heat and gas options are compared with natural gas only when calculating the avoided $\mathrm{CO}_{2}$.

\section{Competition for budget under the SDE+}

Figure 3 shows for the period 2010-2014 the annual production of renewable energy in the Netherlands receiving operational support from the current SDE+ scheme and its predecessors. This production accounted for around one third of total renewable energy production in 2014 which was 30.8 million MWh (Statistics Netherlands (CBS) 2015). Figure 3 clearly shows that most operational support goes to renewable electricity. ${ }^{10}$

\footnotetext{
${ }^{9}$ Note that this is different from the penalization discussed in the "Why does Europe have a renewable energy target based on final energy?" section, which is about the smaller contribution of wind and solar to renewable energy statistics when expressed in primary energy. To summarize: the choice for a final energy-based target is positive for wind when looking at its contribution to the renewable energy target, but negative for wind when looking at its position on the least cost ranking.

${ }^{10}$ The amount of renewable energy production that got operational support declined in recent years mainly because of less biomass co-firing in coal-fired power plants as the plants involved ran out of their support period.
} 
Fig. 1 Relation between support euros expressed per GJ primary energy versus GJ final energy. Electricity options are marked with an " $x$ ", heat and gas options with a " $\diamond "$

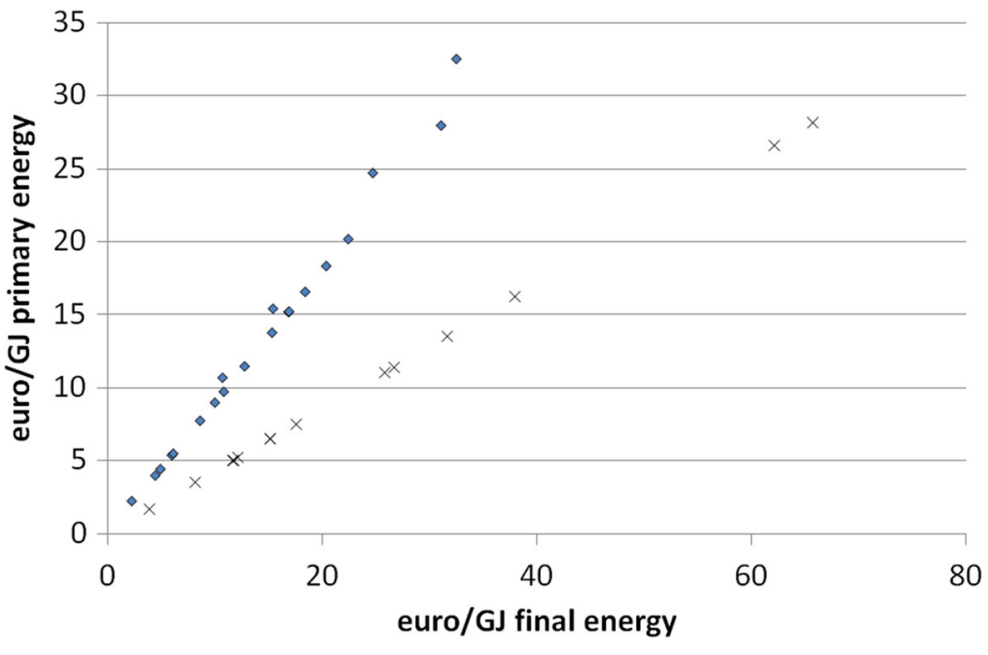

Since 2012 renewable heat projects can also apply for SDE+ subsidy. ${ }^{11}$ Because of the time period between the application for a subsidy, the realization of a project and the actual production of renewable energy, only a limited amount of subsidy was actually paid to renewable heat projects in 2012 (see Fig. 3). As Fig. 4 shows, however, the majority of the 2012 SDE+ budget (EURO 1.7 billion) was granted to renewable heat projects. ${ }^{12}$

The question is to what extent we can explain the 2012 budget allocation with the change of metrics in the target definition combined with the possibility for renewable heat projects to apply for SDE+ subsidy. To phrase it differently: did developers of renewable electricity projects not apply for subsidy in 2012? And if this was indeed the case: why not? An indicative answer can be derived from Fig. 5 which shows the realized and expected (from wind farms not yet built) production of onshore wind electricity from granted $\mathrm{SDE}(+)$ subsidy in the period 2008-2014.

Figure 5 shows that after the introduction of SDE + in 2011 the amount of new onshore wind projects (expressed in million kilowatt hour electricity production)

\footnotetext{
${ }^{11}$ This refers to renewable heat only. Renewable CHP projects could already apply for support before 2012 .

${ }^{12}$ A similar situation is found in 2011 where the majority of the budget was granted to renewable gas projects. The cases of renewable heat and gas are highly comparable. As Table 2 shows, both options have a much better position in the ranking compared to electricity options when the cost-effectiveness is based on final energy. Although the remaining of the paper mainly uses renewable heat for illustration of the argument, the reader should keep in mind that the analysis is equally relevant to renewable gas.
}

was small in 2011 and $2012,,^{13} 2$ years in which the majority of the budget was granted to renewable gas and heat projects (see Fig. 4). As the subsidy granted to wind increased again in 2013 and 2014, it seems that the explanation of the small amount of wind applications in 2011 and 2012 is to be found in the subsidy instrument and most likely not in external factors. Here, it is important to stress that a granted subsidy does not always lead to project realization, e.g. if a project developer is not able to reach financial close or if local opposition against a renewable energy project (whether it is wind, biodigestion or geothermal) is too fierce.

Based on the data gathered, it seems that a combination of a limited SDE+ budget in 2011 and 2012 (1.5 and 1.7 billion respectively, and increased to 3 and 3.5 billion in 2013/14; see Fig. 4), the competition for budget between gas and electricity since 2011, heat, gas and electricity since 2012 and the changed metrics in the renewable energy target definition (determining the ranking of low cost options, see Table 2) have led to the underexposure of renewable electricity options (using wind for illustration) in the granting of SDE+ subsidies in 2011 and 2012.

This competition for budget can be further illustrated by the SDE+ 2012 and 2013 data for onshore wind, offshore wind and geothermal energy published by the Netherlands Enterprise Agency (RVO.nl 2012, 2014). In Table 3 these data are compared with the renewable

\footnotetext{
$\overline{13}$ The relatively small amount of new wind energy in 2008 might be related to the introduction of a new subsidy scheme in that year, making project developers "wait and see". In the period 20082010 , onshore wind had its own SDE budget and did not have to compete with the other renewable options.
} 
Fig. 2 Relation between support euros expressed per ton $\mathrm{CO}_{2}$ reduced versus GJ primary energy. Electricity options are marked with an " $x$ ", heat and gas options with a " $\diamond$ "

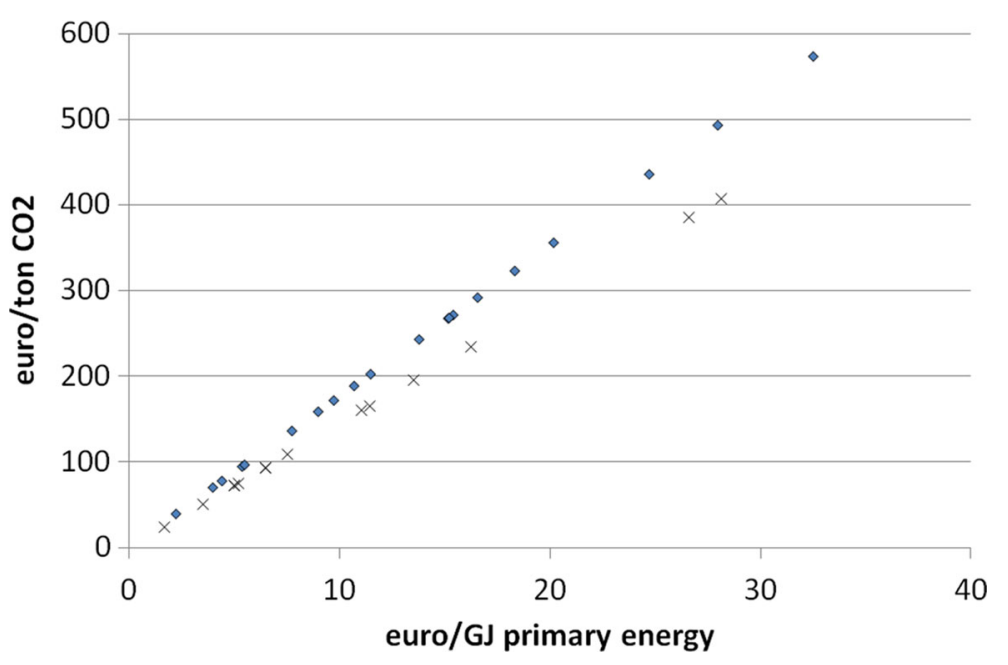

energy production from these technologies in 2013 (Statistics Netherlands (CBS) 2014) and the projected renewable energy production in the Dutch National Renewable Energy Action Plan (NREAP 2010).

For offshore wind, it becomes clear from Table 3 that the 2012-2013 system of budget allocation in the SDE+ scheme would not lead to new offshore wind farms. In the meantime, this has been recognized by the Dutch government and a separate tendering system for offshore wind has been announced (Hekkenberg et al. 2013).

For onshore wind the annual production from newly to develop projects that were granted subsidy in 2012

\section{2 (million MWh)}

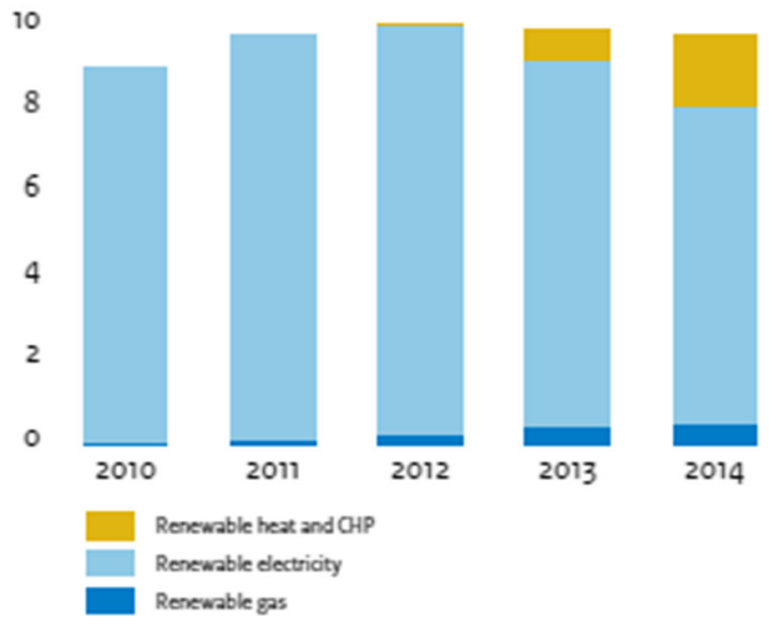

Fig. 3 Total annual renewable energy production (megawatt hour final energy) from subsidy programmes (SDE + and predecessors) (RVO.nl 2015)
(0 PJ/year) and 2013 (3.1 $\mathrm{PJ} /$ year) will be small to modest. A significant amount of newly to develop onshore wind projects in the period 2014-2020 is needed (31.5 PJ/year, see last column in Table 3) in order to meet the onshore wind goal set for 2020. This requires a growth from about $2600 \mathrm{MWe}$ onshore wind capacity at the end of 2014 to $6000 \mathrm{MWe}$ in 2020 . Continuation of the 2013 trend would lead to a gap of $9.8 \mathrm{PJ}$ in 2020 $(31.5-(7 \times 3.1))$.

Finally, geothermal energy would overachieve its 2020 goal if all projects that were granted SDE + subsidy in 2012 and 2013 are actually realized (delivering (8.1+ 3.2) $\mathrm{PJ} /$ year which is more than the $9.8 \mathrm{PJ} /$ year (last column) aimed for in the NREAP). ${ }^{14}$ Any additional geothermal projects which would be granted subsidy and would be realized in the period 2014-2020 would contribute to overachieving the 2020 goal of the NREAP.

Based on Table 3 data, it can be concluded that geothermal energy is one of the winners regarding the competition for budget, at the expense of wind energy, at least in 2012. Whether this competition is beneficial for Dutch target achievement is doubtful. The indicative production figures for the various renewable energy technologies in the Dutch NREAP are based on potential deployments up to 2020 taking into account the (im)maturity of the supply chain of the various renewable energy technologies. This implies that, although geothermal might become much bigger than reported

\footnotetext{
${ }^{14}$ Again, note that actual project realization depends on other variables such as access to capital which is not necessarily secured in all projects to which a subsidy is granted.
} 
Fig. 4 Allocation of the available $\mathrm{SDE}+$ budget for each renewable energy category (RVO.nl 2015) including the annual SDE+ budget in euros (2010 has been removed from the original figure as this concerns the previous support scheme.)

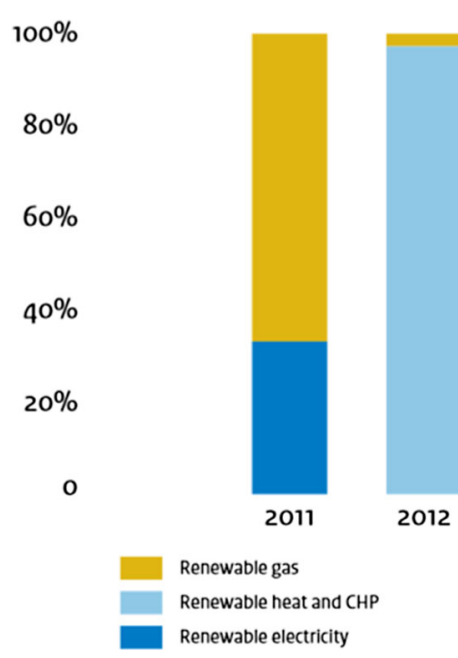

SDE+ budget: $2011-€ 1.5$ billion $2012-€ 1.7$ billion $2013-€ 3.0$ billion $2014-€ 3.5$ billion in the NREAP (as it is an option that literally started from zero) it is unlikely that the bigger amount of geothermal energy can compensate for a reduced amount of wind production in 2020. In addition, it is not beneficial for the investment climate for wind energy that the available subsidy budget for the technology fluctuates so strongly.

As indicated in Fig. 4, the competition for budget has become less fierce in the past years because of a budget increase. Whereas the total SDE+ budget in 2012 was $€ 1.7$ billion, it was increased to $€ 3$ billion in 2013 (of which 2.967 has been granted) and to $€ 3.5$ billion in
2014 (and 2015). Figure 4 shows that with an increasing budget, renewable electricity is able to increase its share in the total budget allocation.

\section{Discussion and conclusion}

The objective of this paper was to analyse the impact of the use of different metrics/physical terms in the EU renewable energy target definition and to identify lessons for policy design. In this section, we draw conclusions and discuss our findings.
Fig. 5 Onshore wind electricity production (realized/expected) from SDE and SDE+ (RVO.nl 2015)

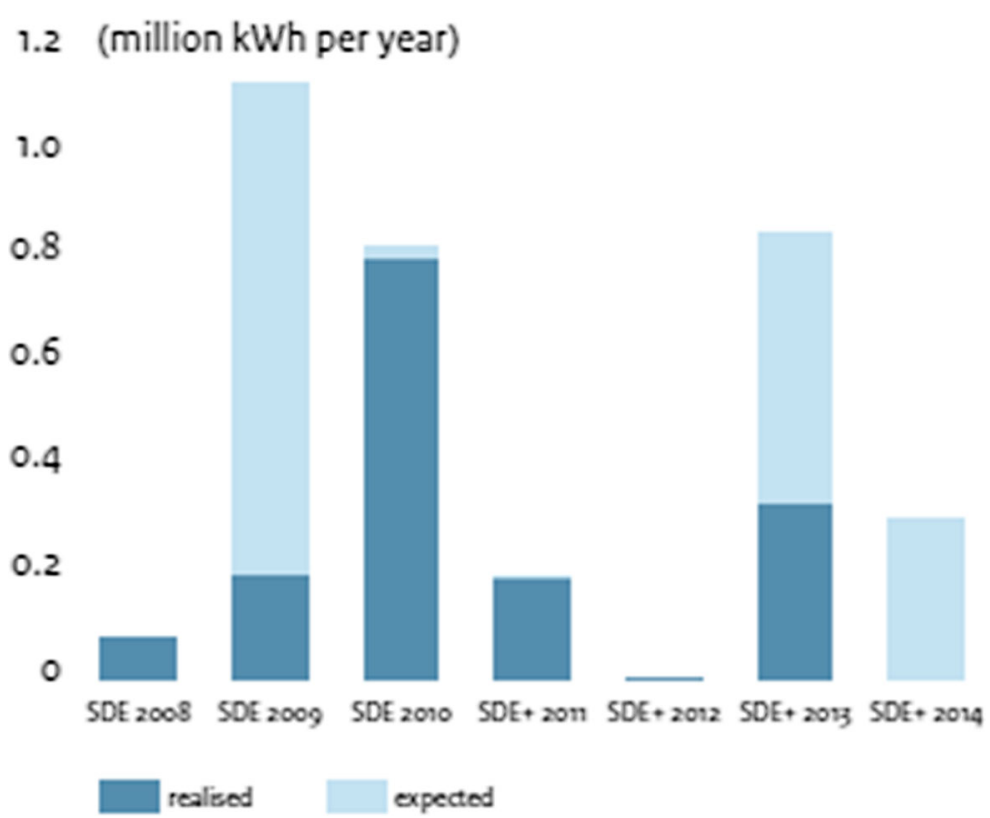




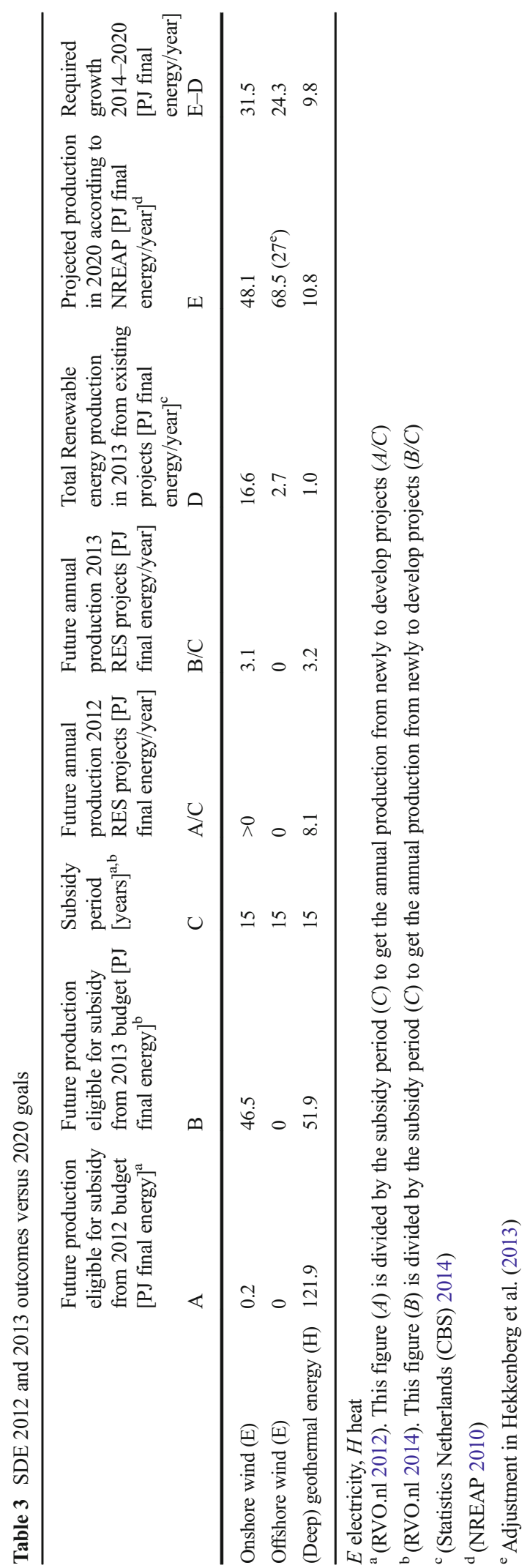

What is the impact of the use of different metrics/ physical terms in the EU renewable energy target?

The 2020 EU renewable energy target is defined as a share of renewable energy in total final energy consumption. The choice of the European Commission to not base the target on primary energy (which was practised before) was made to ensure a level playing field between wind and biomass electricity in the renewable energy statistics. A target based on primary energy would mean that the same amount of wind or biomass electricity results in a bigger share of biomass in renewable energy output since biomass-to-electricity conversion efficiencies are around $40 \%$ (1 $\mathrm{kWh}$ electricity $=2.5 \mathrm{kWh}$ primary energy) whereas wind is considered $100 \%$ efficient in statistics $(1 \mathrm{kWh}$ electricity $=1 \mathrm{kWh}$ primary energy).

With the implementation of the (binding) renewable energy target based on final energy in the Netherlands, the Dutch support scheme for renewable energy (SDE+) ranked renewable heat and gas options predominantly higher than renewable electricity options, meaning that renewable heat and gas were considered the cheapest for realizing the target. In line with that, in the period 20112014, most of the SDE+ support has been allocated to renewable heat and gas projects. This became an issue since (1) new renewable electricity projects were supported from the same budget as renewable heat and gas projects and (2) the annual budget was limited, especially in 2011 and 2012. Budget cuts in renewable support (despite a gap towards the target) are not uncommon and took also place in Spain where the support scheme for solar PV was stopped in January 2012 as support costs exploded from 215 million in 2007 to 2.8 billion in 2009 (Del Rio and Cerda 2014). Such a large burden for consumers (who pay via a surcharge on their electricity bill) was considered economically unsustainable, socially unacceptable and politically unfeasible. These arguments were also used in the Netherlands to limit the annual support budget.

\section{Lessons for policy design}

In their study on policy interaction, Oikonomou et al. (2012, p.177) state that "given the complex policy environment, various objectives are pursued in terms of environmental and energy effectiveness, alongside with economic efficiency". A complementary insight is given 
by Meadows (2008, p.85) stating that "when a subsystem's goals dominate at the expense of the total system's goals, the resulting behaviour is called suboptimization." McDonnell and Grub (1991, p.10) posit that “...policy design is often hampered by analysts' and policymakers' inability to diagnose a problem correctly." Merton (1936) listed five sources for so-called unintended or unanticipated consequences of purposive social action which may also be reflected in many policy designs: ignorance, error, imperious immediacy of interest (intended ignorance), basic values and selfdefeating prediction.

The 2009 RES Directive and its translation into Dutch national policies offer a good example of these quotes from scientific literature: linking to the quote of Oikonomou et al. (2012), it is important to realize that the EU renewable energy target is not a goal in itself. On the contrary: renewable energy is considered by the European Commission a means to combat climate change, to improve security of energy supply, to promote technological development and innovation and to provide opportunities for employment and regional development. The objective of the Dutch renewable support scheme $\mathrm{SDE}+$ is, however, to meet the renewable target in a least cost way, without a focus on dynamic efficiency and the overarching objectives of the Directive. ${ }^{15}$ In terms of Meadows (2008), it can be stated that the goal of the Dutch government ("subsystem") to achieve its 2020 target as cheap as possible giving priority to today's lowest cost technologies is not in line with the goals of the European Union ("system") aiming at long-term objectives, with suboptimization as a consequence. Whether the Dutch government diagnosed the problem incorrectly (cf. McDonnell and Grub 1991), resulting in the unanticipated consequences (cf. Merton 1936) as shown in Fig. 4 offers an interesting question: was it ignorance, intended ignorance or simply an error?

Regarding lessons for policy design, for the EU, one explicit argument (more pronounced role of wind in the renewable energy share) and one implicit argument (incentive for increasing the contribution of renewable heat) can be identified to justify the choice for a renewable energy target based on final energy. Although the arguments are well understood, it may be questioned

\footnotetext{
${ }^{15}$ The separate tendering system for offshore wind that has been set up in the meantime does support dynamic efficiency and the overarching objectives more explicitly.
}

whether these are strong enough to justify a target that is less connected to two important overarching objectives of EU policy (combat climate change and improve energy security) than a target based on primary energy. As the figures in Table 1 show, the contribution of wind, hydro and solar power is lower in terms of primary energy but not extremely lower than in terms of final energy. Maybe the European Commission would have come to a similar conclusion if the design of the renewable energy target would have been evaluated against a wider set of criteria than looking on the share of wind in renewable energy statistics alone, even wider than climate change and energy security but looking at all objectives of the 2009 RES Directive. These lessons for policy design may be relevant for the renewable energy policy beyond 2020 .

Acknowledgments Four anonymous reviewers are gratefully thanked for their useful and constructive feedback.

Open Access This article is distributed under the terms of the Creative Commons Attribution 4.0 International License (http:// creativecommons.org/licenses/by/4.0/), which permits unrestricted use, distribution, and reproduction in any medium, provided you give appropriate credit to the original author(s) and the source, provide a link to the Creative Commons license, and indicate if changes were made.

\section{References}

Blarke, M. B., \& Lund, H. (2008). The effectiveness of storage and relocation options in renewable energy systems. Renewable Energy, 33, 1499-1507.

Buck te, S., Keulen van, K., Bosselaar, L., Gerlagh, T. (2010). Protocol monitoring hernieuwbare energie (Protocol monitoring renewable energy) — update 2009. May, NL Agency (now RVO.nl).

Capros P., De Vita A., Tasios N., Papadopoulos D., Siskos P., Apostolaki E., Zampara M., Paroussos L., Fragiadakis K., Kouvaritakis N. (2013). EU energy, transport and GHG emissions - trends to 2050-reference scenario 2013. Report for the European Commission.

European Parliament and Council (2009). Directive 2009/28/EC of the European parliament and of the council of 23 April 2009 on the promotion of the use of energy from renewable sources.

Del Rio, P., \& Cerda, E. (2014). The policy implications of the different interpretations of the cost-effectiveness of renewable electricity support. Energy Policy, 64, 364-372.

European Commission (2007). Renewable energy road map. Renewable energies in the $21^{\text {st }}$ century: building a more sustainable future. $\operatorname{COM}(2006) 848$ final. 
European Commission (2008a). Communication from the commission-20 20 by 2020: Europe's climate change opportunity. COM(2008) 30 final.

European Commission (2008b). Joint impact assessment on the package of implementation measures for the EU's objectives on climate change and renewable energy for 2020 . SEC(2008) 85.

European Commission (2015). Renewable energy progress report. COM(2015) 293 final.

Eurostat Statistics (2013). nrg_122a, nrg_123a, nrg_124b. 2013 data

Haas, R., Resch, G., Panzer, C., Busch, S., Ragwitz, M., \& Held, A. (2011). Efficiency and effectiveness of promotion systems for electricity generation from renewable energy sources: lessons from EU countries. Energy, 36, 2186-2193.

Harmsen, R. (2014). Interpreting cost-effectiveness: target definitions versus policy objectives. IEPPEC conference, 9-11 September 2014, Berlin.

Harmsen, R., \& Graus, W. (2013). How much $\mathrm{CO}_{2}$ emissions do we reduce by saving electricity? A focus on methods. Energy Policy, 60, 803-812.

Harmsen, R., Wesselink, B., Eichhammer, W., \& Worrell, E. (2011). The unrecognized contribution of renewable energy to Europe's energy savings target. Energy Policy, 39(6), 3425-3433.

Hekkenberg, M., Londo, H.M. \& Lensink, S. (2013). Toelichting inschatting korte-termijn effecten Energieakkoord op hernieuwbare energie. ECN, ECN-E-13-044.

IEA \& Eurostat. (2005). Energy statistics manual. Paris: International Energy Agency.

Kle $\beta$ mann, C. (2011). Increasing the effectiveness and efficiency of renewable energy support policies in the European Union, $\mathrm{PhD}$ thesis, Utrecht University.

Kleßmann, C., Held, A., Rathmann, M., \& Ragwitz, M. (2011). Status and perspectives of renewable energy policy and deployment in the European Union - what is needed to reach the 2020 targets? Energy Policy, 36(12), 7637-7657.
Kleßmann, C., Rathmann, M., de Jager, D., Gazzo, A., Resch, G., Busch, S., \& Ragwitz, M. (2013). Policy options for reducing the costs of reaching the European renewables target. Renewable Energy, 57, 390-403.

Lensink, S. (2013). Final advice base rates SDE+ 2014. ECN, ECN-E-13-051.

McDonnell, L., \& Grub, W. N. (1991). Education and training for work: the policy instruments and the institutions. Santa Monica: The Rand Corporation.

Meadows, D. H. (2008). Thinking in systems: a primer. Edited by Diana Wright. Chelsea Green Publishing, Vermont.

Merton, R. (1936). The unanticipated consequences of purposive social action. American Sociological Review, 1(6), 894-904.

NREAP (National renewable energy action plan) Directive 2009/28/ EC (2010). http://ec.europa.eu/energy/renewables/action_plan en.htm.

Oikonomou, V., Flamos, A., Zeugolis, D., \& Grafakos, S. (2012). A qualitative assessment of EU energy policy interactions. Energy Sources, Part B: Economics, Planning and Policy, $7(2), 177-187$.

Palmer, K., \& Burtraw, D. (2005). Cost-effectiveness of renewable electricity policies. Energy Economics, 27, 873-894.

RVO.nl (2012). Tabellen stand van zaken SDE+ 2012. Final status.

RVO.nl (2014). Tabellen stand van zaken SDE+ 2013. Final status.

RVO.nl (2015). 2014 Report on renewable energy annual report on SDE+, SDE, MEP and OV-MEP.

Statistics Netherlands (CBS) (2014). Renewable energy in the Netherlands 2013. August, The Hague/Heerlen.

Statistics Netherlands (CBS) (2015). Renewable energy in the Netherlands 2014. August, the Hague/Heerlen.

Toke, D. (2007). Renewable financial support systems and costeffectiveness. Journal of Cleaner Production, 15, 280-287.

Vedung, E. (2013). Six models of evaluation. In: Routledge Handbook of Public Policy, edited by Araral, E., Fritzen, S., Howlett, M., Ramesh, M. and Wu, X. Routledge Handbooks. 